\title{
Eliminating the Board of Pharmacy's Role in Designating a Pharmacist-in-Charge
}

Alex J. Adams, PharmD, MPH

Idaho Division of Financial Management

\begin{abstract}
Nearly all states require that each licensed pharmacy designate a pharmacist-in-charge (PIC). By law, the PIC typically has responsibility for all professional practice laws and facility standards laws and can be held accountable for such. However, the extent to which the PIC has actual authority over many facility standards varies by organization. This can seemingly put a target on the back of the PIC for decisions they wield little authority over. Idaho recently removed the legal references to the PIC, signaling that facilities are responsible for facility standards and insulating pharmacists from discipline for matters that are outside their control.
\end{abstract}

Recently the Idaho Board of Pharmacy amended its regulations to remove all references to the "pharmacist-in-charge" (PIC) from its laws governing in-state pharmacies. ${ }^{1-2}$ No longer will the board require pharmacies to designate a PIC. Similarly, all references to the responsibilities of a PIC were removed. This is a shift in orthodoxy driven by the board's desire to strike a better balance in accountability of individual pharmacists and the organization for which the pharmacist is employed. This letter will briefly outline the rationale in making this change to assist other states considering similar issues.

\section{What exactly is the "Pharmacist-in-Charge" in Charge of?}

Nearly all states require that each licensed pharmacy designate a PIC. While state laws vary with respect to the responsibilities of a PIC, Idaho provided a representative example. Namely, a PIC was responsible for "the management of every part of the drug outlet and its regulated operations." ${ }^{1}$ Additionally, "[t]he PIC and the drug outlet each have corresponding and individual responsibility for compliance with applicable state and federal law and these rules."

Further rules specified three express requirements with more granularity:

1. Oversight Limitations: "A person may not be designated nor function as the PIC for more than two (2) drug outlets concurrently."

2. Reporting requirements: "Both an outgoing and an incoming PIC must report to the Board a change in a PIC designation within ten (10) days of the change."

3. Inventory Requirements: "A complete controlled substance inventory must be conducted by the incoming PIC or his delegate on or by the first day of employment of the incoming PIC."1

Corresponding author: Alex J. Adams, PharmD, MPH Former Executive Director, Idaho State Board of Pharmacy Current Administrator, Idaho Division of Financial Management; Email: AlexAdamsRPh@gmail.com
Of note, each of these specifically delineated roles varies by state. State oversight limitations vary from requiring the PIC to work 32 hours per week at the location they oversee to states not listing any express oversight requirements. Reporting requirements vary from 24 hours to 30 days. Moreover, several states - and the U.S. Drug Enforcement Administration - do not require an inventory on change in PIC.

Thus, state laws related to PICs create a confusing patchwork of specific callouts, but in general they are broad and allencompassing with respect to requiring the PIC be responsible for all laws. Beyond the legal responsibilities, PICs may be assigned traditional management roles by the employer, such as staff training, performance evaluation, and scheduling, among other duties. ${ }^{3}$

\section{PIC Responsibility vs. Authority}

By law, the PIC typically has responsibility for all professional practice laws and facility standards laws and can be held accountable for such. However, the extent to which the PIC has actual authority over many facility standards varies by organization. In a chain pharmacy, many decisions are made at the district, regional, or corporate level that the PIC has little influence over. In both community and hospital settings, the PIC may even report to non-pharmacists who have their own goals and values that, at times, may conflict with the PIC.

Given this potential conflict in individual versus facility responsibilities, one state's PIC guidance document attempted to assuage pharmacists concerns by stating: "Pharmacists should not be fearful that, by merely being the PIC of a pharmacy, they will be the subject of Board action for circumstances which are beyond their control."4 This reassurance clashes with the experience of some. For example, one pharmacy executive shared his lessons learned with emerging leaders and lamented: “...the state does not care about your organizational structure or whether you had the appropriate authority to control the medication use system in your institution. You are in charge legally. Failure to exert this state-granted authority can result in a loss of your license, a fine, and a series of other consequences." ${ }^{5}$ 
One state even applied a strict liability standard and held a PIC responsible for the action of a subordinate personnel even when the PIC was unaware of the behavior. ${ }^{6}$ Idaho, meanwhile, had levied discipline against PICs for allowing individuals to work at the pharmacy who had failed to renew their licenses on time, for having systems that reported incorrect information to the state's Prescription Drug Monitoring Program, and for having expired products among the pharmacy's active inventory. While the PIC was legally responsible for these violations, to what extent did the PIC have the authority to make decisions that could have mitigated the risk of each of these violations occurring?

\section{Balancing Accountability: Individuals vs. Facilities}

Thus, there exists a schism between the role the PIC is expected to play under state law, and the authority the PIC actually plays within the company. This can seemingly put a target on the back of the PIC for decisions they wield little authority over.

Maryland came the closest to deferring solely to the employeremployee relationship with respect to pharmacy, having a law that states that each pharmacy "shall appoint a licensed pharmacist as director who shall...be in full and actual charge of the pharmacy and its personnel."7 Thus, a PIC is not registered with the board, and the board has thus not inserted itself into the employer-employee relationship.

Idaho adapted the Maryland approach, and removed all references to the PIC from law. To the extent a facility standard requirement is violated (e.g., an inventory not having been completed as required), the board will pursue disciplinary action against the facility, not an individual who had been identified as the PIC. If the employer had designated a specific individual to have completed the inventory, that is a matter for the employer to address with its employee. In other words, facility standards are the responsibility of the facility, not the individual pharmacist.

It is anticipated that each organization will still designate a "pharmacy manager" or "director of pharmacy" to handle traditional management responsibilities. The scope of responsibilities for these roles would be outlined by the organizations as part of the position description, not the board of pharmacy.

\section{Recommendations}

Idaho's removal of the PIC designation occurred against a backdrop of broader regulatory reform. In recent years, Idaho has made significant expansions in pharmacist roles, enabling independent prescriptive authority and prescription adaptation services, while simultaneously reducing the overall regulatory word count and number of restrictions. ${ }^{8-10}$ Idaho also enabled pharmacy technicians to play a greater role with both dispensing and technical support for pharmacist-provided clinical services to free up pharmacists for more advanced care. ${ }^{11-12}$
The board saw these efforts as intertwined: elevating the role of the pharmacist as a healthcare professional and liberating pharmacists from the burden of feeling legally responsible for matters they may not actually have authority over. By removing the legal references to the PIC, the board of pharmacy has signaled that facilities are responsible for facility standards. Other boards of pharmacy may want to consider eliminating the PIC.

Funding Support: None

Conflicts of Interest: None

Disclaimer: The views expressed in this manuscript are those of the authors alone, and do not necessarily reflect those of the employer.

Acknowledgments: None

\section{References}

1. Idaho Administrative Bulletin. Docket No. 27-01031801. October 3, 2018. Available from: https://adminrules.idaho.gov/bulletin/2018/10.pdf (Accessed July 4, 2020)

2. Adams AJ. Transitioning Pharmacy to "Standard of Care" Regulation: Analyzing how Pharmacy Regulates Relative to Medicine and Nursing. Res Social Adm Pharm. 2019 Oct;15(10):1230-35. Doi: 10.1016/j.sapharm.2018.10.008.

3. RxRelief. Pharmacy Career Options: Pharmacist in Charge. The Script. September 23, 2013. Available from: https://rxrelief.com/blog/pharmacy-careeroptions-pharmacist-charge\#.W g6Ti-ZMIU (Accessed July 4, 2020)

4. Virginia Board of Pharmacy. Checklist of PIC Responsibilities. Available from:

https://www.google.com/url?sa=t\&rct=j\&q=\&esrc=s \& source $=$ web\&cd=8\&ved=2ahUKEwjq8qvoiOveAhUL h1QKHSq8AKsQFjAHegQICRAC\&url=https\%3A\%2F\%2 Fwww.dhp.virginia.gov\%2Fpharmacy\%2Fguidelines\% 2F110-

27.doc\&usg=AOvVaw0uXbSrjuyP888Wr84oXDJ3

(Accessed July 4, 2020)

5. Mark SM. Things I Wish I Had Known Before Becoming a Pharmacy Leader. Hosp Pharm. 2013;48(1):68-76. Doi: 10.1310/hpj4801-68

6. Fink JL. Is a Pharmacist-in-Charge Responsible for a Technician's Drug Diversion? Pharmacy Times. July 26, 2017. Available from: https://www.pharmacytimes.com/publications/issue 2017/july2017/is-a-pharmacistincharge-responsiblefor-a-technicians-drug-diversion (Accessed July 4, 2020)

7. Maryland Breg Section 10.34.03.05. Personnel. Available from: http://www.dsd.state.md.us/comar/comarhtml/10/1 0.34.03.05.htm (Accessed July 4, 2020) 
8. Adams AJ. Pharmacist Prescriptive Authority: Lessons from Idaho. Pharmacy. 2020;8:112. Doi: 10.3390/pharmacy8030112

9. Adams AJ. Prescription Adaptation Services: A Regulatory and Practice Perspective. Ann Pharmacother. 2018 Mar 1. doi: 10.1177/1060028018763883.

10. Adams AJ, Chopski NL. Rethinking Pharmacy Regulation: Core Elements of Idaho's Transition to a "Standard of Care" Approach. J Am Pharm Assoc. 2020. In Press.

11. Adams, AJ. Advancing technician practice: Deliberations of a regulatory board. Res. Soc. Adm.

Pharm. 2018, 14, 1-5, doi:10.1016/j.sapharm.2017.02.008.

12. Bright $D$, Adams AJ. Pharmacy TechnicianAdministered Immunizations in Idaho. American Journal of Health-System Pharmacy. 2017;74(24):2033-2034.

https://doi.org/10.2146/ajhp170158 